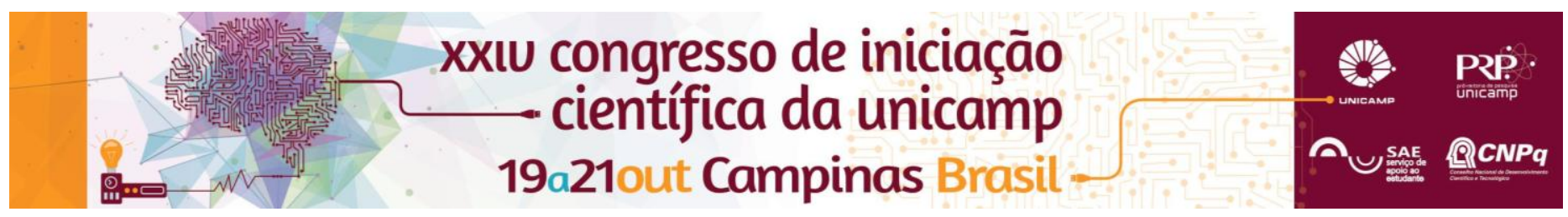

\title{
MONITORAMENTO DE SISTEMAS SUSTENTÁVEIS DE TRATAMENTO DE ÁGUAS RESIDUÁRIAS COM PRODUÇÃO DE BIOGÁS
}

\author{
Gabriela R. Machado*, Lucas F. de Araújo, Tauany S. Vieira, Érika R. Moretti (monitora), Julyenne M. Campos \\ (monitora), Denis M. Roston (orientador).
}

\begin{abstract}
Resumo
Wetlands construídas (WL) tratam de esgoto utilizando-se macrófitas para retirar matéria orgânica e outros nutrientes do meio. Porém, visto que as macrófitas devem ser podadas quando começam a mostrar-se ineficientes na absorção dos poluentes, gera-se resíduo. Este resíduo vegetal deve ter destinação sustentável e uma opção é a produção de biogás (BG) por digestão anaeróbia (DA). As WL estudadas removeram de 45 a $73 \%$ de cor aparente, 28 a $53 \%$ de demanda química de oxigênio (DQO), e manteve o pH do meio entre 6,2 e 7,1. Para a DA de taboa residual, utilizaram-se duas granulometrias identificando-se que a moagem grosseira produziu 3,6 L de BG e a fina produziu 3,4 L em 42 dias, não havendo diferença expressiva. Assim conclui-se que WL são sistemas sustentáveis tanto pelo eficiente tratamento de esgoto quanto pela possibilidade de geração de composto energético a partir de seu resíduo.
\end{abstract}

\section{Palavras-chave}

Wetlands construídas, hormônio, digestão anaeróbia.

\section{Introdução}

Wetlands construídas são sistemas simplificados de tratamento de esgoto no qual macrófitas aquáticas consomem matéria orgânica e outros nutrientes do esgoto para se desenvolverem. O resíduo de macrófitas gerado nas WL pode ser utilizado para produção de biogás, por meio da digestão realizada por bactérias metanogênicas. O biogás é composto de metano, que pode ser utilizado para a geração de calor e eletricidade, por exemplo. O objetivo do projeto foi estudar wetlands construídas no tratamento de esgoto, avaliando a remoção de nutrientes existentes, além de utilizar seus resíduos vegetais na produção de biogás.

\section{Resultados e Discussão}

O sistema de WL em escala laboratorial apresentou $\mathrm{pH}$ afluente médio de 6,2; e 7,0 para efluente, o que indica que o meio age como um tampão. A DQO média afluente foi $273 \mathrm{mg} . \mathrm{L}^{-1}$ e efluente $163 \mathrm{mg} . \mathrm{L}^{-1}$, com remoções entre 28 e 53\%. Em média, a cor aparente do afluente foi de 358 $\mathrm{mg} . \mathrm{L}^{-1}$ PtCo para $151 \mathrm{mg} . \mathrm{L}^{-1}$ PtCo no efluente, com remoções médias de 45 a 73\%. Na Figura 1 apresenta-se o conjunto de WC.

Figura 1. Conjunto de wetlands construídas laboratoriais.

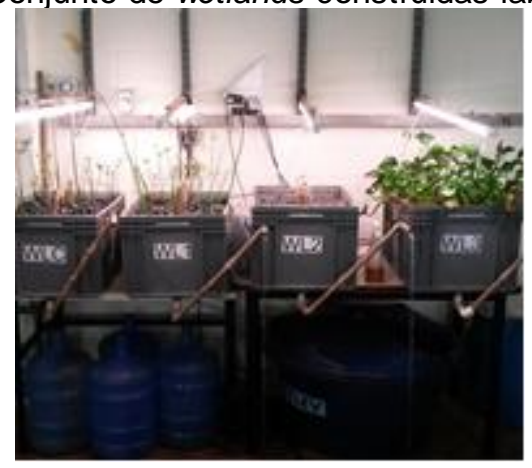

Para a digestão anaeróbia de macrófita, que pode ser residuária de uma WL, utilizou-se a taboa. Ela foi fragmentada em duas granulometrias a fim de verificar diferentes respostas em produção de biogás (Tabela 1).

Tabela 1. Produção de biogás nas diferentes granulometrias.

\begin{tabular}{ccc}
\hline Moagem & $\begin{array}{c}\text { Granulometria } \\
(\mathbf{m m})^{\star}\end{array}$ & $\begin{array}{c}\text { Volume de biogás } \\
(\mathbf{m L})\end{array}$ \\
\hline Grossa & 2,38 & 3.574 \\
Fina & 0,59 & 3.448 \\
\hline
\end{tabular}

*majoritária

Como se observa na Tabela 1 , não houve diferença significativa em volume de biogás produzido pela DA de ambas granulometrias. Assim demonstrou-se que, para a taboa nas condições estudadas, não se justificativa maior gasto energético com fragmentação, já que não resulta em maior produção de biogás.

Ademais, obteve-se mais de $3 \mathrm{~L}$ de biogás em reatores de $900 \mathrm{~mL}$, com concentração de $26 \mathrm{~g} / \mathrm{L}$ de taboa após 42 dias de DA. Supondo-se um reator em maior escala, com 10.000L (por exemplo), utilizando-se a mesma concentração de taboa, resultaria em mais de $33 \mathrm{mil} L$ de biogás disponíveis para aquecimento, por exemplo.

Com isto, mostra-se mais uma vantagem das WL, uma vez que, além de remover poluentes de águas residuárias, elas podem fornecer material capaz de gerar energia.

\section{Conclusões}

Em relação às $W L$ laboratoriais conclui-se que, apesar de da retenção de poluentes ser inferior às $W L$ à luz solar, o sistema apresentou taxas satisfatórias de remoção de DQO e cor aparente, e a partir de sua digestão anaeróbia é possível a geração de um composto energético com seu resíduo, tornando as WL sustentáveis.

\section{Agradecimentos}

Os autores agradecem ao SAE e ao CNPq pelas bolsas PIBIC-EM; à CAPES e ao CNPq (149364/2014-8) pelas bolsas de doutorado das monitoras; ao FAEPEX pelo auxílio concedido, à PRP e à UNICAMP. 